\title{
Cheap Imports and the Loss of U.S. Manufacturing Jobs
}

\author{
Thomas Kemeny $^{* \dagger}$, David Rigby ${ }^{\dagger \dagger}$ and Abigail Cooke ${ }^{\dagger \dagger}$ \\ ${ }^{\dagger}$ Department of Geography \& Environment, London School of Economics \\ ${ }^{\dagger \dagger}$ Department of Geography, UCLA
}

\author{
Please cite published version: \\ Kemeny, T., Rigby, D., \& Cooke, A. (2014). Cheap Imports and the Loss of US \\ Manufacturing Jobs. The World Economy. DOI: 10.1111/twec.12238.
}

\begin{abstract}
This paper examines the role of international trade, and specifically imports from lowwage countries, in determining patterns of job loss in U.S. manufacturing industries between 1992 and 2007. Motivated by intuitions from factor-proportions-inspired work on offshoring and heterogeneous firms in trade, we build industry-level measures of import competition. Combining worker data from the Longitudinal Employer-Household Dynamics dataset, detailed establishment information from the Census of Manufactures, and transaction-level trade data, we find that rising import competition from China and other developing economies increases the likelihood of job loss among manufacturing workers with less than a high school degree; it is not significantly related to job losses for workers with at least a college degree.
\end{abstract}

JEL Classification: F14; F15; F16; F6; J31

Keywords: international trade, import competition, job loss, inequality, manufacturing

Disclaimer: Any opinions and conclusions expressed herein are those of the author(s) and do not necessarily represent the views of the U.S. Census Bureau. All results have been reviewed to ensure that no confidential information is disclosed

Acknowledgements: Kemeny and Rigby gratefully acknowledge support from the National Science Foundation Grant BCS-0961735; the authors also thank Olmo Silva and the LSE Spatial Economics Research Center. This research uses data from the Census Bureau's Longitudinal Employer Household Dynamics Program, which was partially supported by the following National Science Foundation Grants SES-9978093, SES-0339191 and ITR0427889; National Institute on Aging Grant AG018854; and grants from the Alfred P. Sloan Foundation.

\footnotetext{
${ }^{*}$ Corresponding author. Contact information: Department of Geography \& Environment, London School of Economics, Houghton Street, London, WC2A 2AE, UK; e-mail: t.e.kemeny@lse.ac.uk.
} 


\section{Introduction}

During the 1960s, nearly one in three jobs in the U.S. were in manufacturing. As of January 2013, less than 9 percent of all American workers held manufacturing jobs. Manufacturing's relative importance has undergone a sharp decline in most other high-wage developed economies as well, including Britain, France, Germany, Italy and Japan. ${ }^{1}$ In the U.S., as in many of these other economies, the mid-20th century preponderance of well-paid manufacturing jobs underpinned a society defined by its large middle class; the disappearance of these jobs has accompanied large and persistent increases in wage inequality, particularly in terms of the gap between those in the middle of the income distribution and those at the top (Autor et al., 2008). By the early 1990s, the continued decline of manufacturing was linked to growing global integration; in some quarters, 'globalization' became a synonym for a "giant sucking sound" of jobs allegedly fleeing the U.S. in favor of Mexico and other low-wage labor markets. However, researchers at that time concluded that there was simply not enough trade with low-wage economies to produce the observed changes in the domestic labor market (Lawrence et al., 1993; Haskel and Slaughter, 2001). ${ }^{2}$ Though it was acknowledged that some production was relocating from the U.S. to low-wage countries, the consensus view was that the chief cause of both rising inequality and declining manufacturing employment was the widespread adoption of computers in the workplace. Computers and other new technologies, researchers argued, were skill biased: they complemented individuals whose jobs required high levels of skill and abstract thinking, while they substituted for those performing routine, less-skill-intensive work, including many workers on manufacturing production lines (Haskel and Slaughter, 2002; Levy and Murnane, 2004; Goos and Manning, 2007). This technology-based explanation remains highly influential today (Edwards and Lawrence, 2013).

There is at least one major reason to re-consider the labor market impacts of international trade. In a word: China. Accounting for just under $5 \%$ of the total value of U.S. imports from low-wage economies in 1992, by 2007, imports from China had risen to $75 \%{ }^{3}$ China's growing role occurred as imports from low-wage economies rose from a modest $9 \%$ of the total value of U.S. imports in 1992 to $23 \%$ of total imports in 2007, and, in absolute terms, as overall U.S. imports nearly tripled. In short, U.S. imports from low-wage countries have grown dramatically in relative and absolute terms, and China is the primary driver of this change. Observing these trends, a number of prominent researchers and public intellectuals have called for revisiting the impact of trade on wages, job loss and overall welfare (Blinder, 2006; Krugman, 2008; Feenstra, 2010). This call has been taken up in a new wave of empirical work examining how low-wage import competition may be affecting wages, employment, long-term welfare, plant survival, occupational structure (Bernard et al., 2006; Liu and Trefler, 2008; Ebenstein et al., 2009; Autor et al., 2012b,a), but it has not investigated the links between trade and job loss.

This paper contributes to this empirical literature by examining the relationship between low-wage import competition and manufacturing job loss. If imports from developing countries

\footnotetext{
${ }^{1}$ On the basis of industrial employment figures from the OECD STAN database (ISIC 15-37).

${ }^{2}$ Nor did the wage changes occur where standard trade theory predicted they would: across industries.

${ }^{3}$ Figures in this paragraph are authors' calculations made using UN COMTRADE data, with low-wage countries defined according to World Bank classifications in 1992. See Table 1 for a list of countries. Values have been deflated to base-year 2007 .
} 
are low-skill intensive, then growth in these imports should increase relative job loss in work of a similar character in the U.S. In other words, rising imports from China and other low-wage countries should result in job losses for American workers with low skill levels. Meanwhile, the growth of low-wage imports may have neutral or even positive effects on more highlyskilled workers, as the economy re-orients toward production that more closely resembles U.S. comparative advantage. This differential job displacement could be the result of a number of different processes. It might be driven by the closure of manufacturing establishments that produce low-skill produce varieties Bernard et al. (2006). Alternatively, rather than shutting down existing plants may simply shed much of their low-skill labor force as they concentrate on high-sophistication varieties. It could also be the result of strategic decisions to shift the boundaries of the firm's domestic activities in response to shifting trade costs for particular tasks in a vertical production chain (Grossman and Rossi-Hansberg, 2006, 2008; Baldwin, 2006). Firms keep tasks subject to high trade costs onshore, while parts of the production process capturing tasks for which trade costs are sufficiently low will be imported, either through armslength contracting or multinational subsidiary arrangements. To the extent that skilled work is systematically associated with higher trade costs, firms could offshore low-skill tasks while strengthening their specialization in functions that require higher skill levels. These different 'task trade' and 'product variety' explanations, each reflecting different dimensions of shifting comparative advantage, could be simultaneously operating.

To explore the link between low-wage import competition and job loss, transaction-level Census estimates of U.S. imports and exports are first used to estimate the extent to which individual U.S. manufacturing industries are exposed to import competition from low-wage countries. We then relate changes in import competition between 1992 and 2007 to the probability of manufacturing job loss, conditional upon individual demographic and establishment-level characteristics. We consider a worker to have lost her job between two periods when she both switches establishments and suffers a decline in salary. We focus on two categories of workers: low- and high-skill workers. Low skill workers are represented by those with less than a high school degree, while the category of high-skill workers is represented using workers with at least a Bachelor's degree. Establishment-specific characteristics permit modeling of potential heterogeneity in organizational responses to import competition.

The data to capture these individual-, establishment-, firm-, and industry-specific dynamics comes from three restricted-use Census Bureau sources: the Foreign Trade Imports and Exports data; the Longitudinal Employer-Household Dynamics (LEHD) database; and the Census of Manufactures. The LEHD program integrates administrative records from state-specific unemployment insurance (UI) programs with Census Bureau economic and demographic data, providing a nearly universal picture of workers, employers, and their interaction in 30 U.S. states (McKinney and Vilhuber, 2011). The Census of Manufactures, meanwhile, considerably enriches the range of establishment characteristics available in LEHD. These data cover the universe of manufacturing establishments, with surveys conducted quinquennially in years ending in 2 and 7. Among other important establishment characteristics, the Census of Manufactures measures spending on computer equipment, such that we might distinguish between the effects of trade and technological change. Linked together, the trade, worker and establishment 
datasets yield a panel covering 1992, 1997, 2002 and 2007.

In our preferred specifications, we account for potential endogeneity bias arising from the possibility that imports are driven by labor demand shocks by instrumenting for import competition using both an industry- and year-specific measure of low-wage imports into the EU-15, and an industry-year measure of trade costs. Doing so, we find that workers with less than a high-school degree are vulnerable to the rise of imports from low-wage economies, while job security for those with at least a Bachelor's degree is largely unrelated to both levels of and changes in import competition. This differentiated result conforms to the theoretical explanations guiding this research. In keeping with recent heterogeneous-firm extensions of the theory of factor-proportions, as well as the literature on offshoring and task trade, growing imports from China and other low-wage economies results in manufacturing job displacement among those workers with low levels of education. It does not appear to threaten jobs held by more highly-educated manufacturing workers.

The remainder of this paper is organized as follows. Section 2 describes the theory motivating this inquiry, and reviews the findings of the existing empirical literature. Section 3 discusses low-wage import competition and how it has changed over the study period. Section 4 describes the empirical approach and the data. Section 5 presents results and Section 6 concludes.

\section{Literature}

A principal insight of the Heckscher-Ohlin (H-O) trade model is that, given a sufficiently open world economy, countries should specialize in activities that reflect factors of production that they hold in relative abundance. Assuming the U.S. is abundant in skilled labor, and low-wage economies like China are abundant in unskilled labor, then a decline in trade costs should reorient production in the U.S. toward industries that intensively demand workers with higher skill levels, while importing goods from China and other low-wage economies that intensively require less-skilled workers. ${ }^{4}$ Standard H-O models consider that such shifts in specialization and trade occur at the scale of industries. But recent trade models emphasize within-industry heterogeneity, product differentiation, and job search frictions which can nonetheless lead to outcomes that are broadly in line with the theory of factor proportions (Melitz, 2003; Yeaple, 2005; Verhoogen, 2008; Helpman et al., 2010). Bernard et al. (2010), for instance, yield such predictions by assuming that the intensity with which plants employ factors of production signals the factor-intensity of the resulting goods. Concretely, this means that plants whose input intensities reflect a country's comparative advantage in skilled labor will be more resilient in the face of low-wage import competition, while those that abundantly use low-skill labor are likely to be most challenged. In a major empirical contribution, Bernard et al. (2006) find that plant employment and survival are negatively related to the level of industry-specific import competition, and within those industries, more capital-intensive plants are more likely grow and survive. Moreover, they show that some plants respond to import competition by switching industries, shifting to those that more intensively require capital and skill. All of this suggests a 'horizontal' adjustment process to low-wage import competition that is consistent

\footnotetext{
${ }^{4}$ Assuming trade with such developing economies forms a large and/or growing proportion of total U.S. trade.
} 
with factor proportions theory. Both within and between industries, employment shifts toward products that better reflect U.S. comparative advantage. We should expect this adjustment process to reduce manufacturing jobs for less-skilled workers whose wages will increasingly be, in the words of Richard Freeman (1995), set in Beijing.

While the H-O model and its descendants emphasize that local industries or firms grow or decline to the extent that they reflect comparative advantage, the recent 'offshoring' theoretical framework takes a 'vertical' view in which the production process of a given good can be split into a sequence or continuum of tasks, with each task subject to specific trade costs (Feenstra and Hanson, 2001; Antràs et al., 2006; Blinder, 2006; Baldwin, 2006; Grossman and Rossi-Hansberg, $2006,2008)$. The theory of offshoring suggests that, on the basis of these activity-specific trade costs, organizations will determine which stages of production to produce domestically and which to offshore, with offshoring itself accomplished either within the organization through a multinational affiliate or through arms-length transactions. While the results of these various models are strongly dependent on assumptions regarding country size, preferences, the nature of technological change, and the number of production factors, models like that of Grossman and Rossi-Hansberg (2008) suggest that, following factor-proportions intuitions, organizations should offshore those activities in which relevant factors are not held in relative abundance. In the case of high-wage economies like the U.S., this means offshoring production tasks that are intensive in their use of low-skill work. In these models, therefore, offshoring works in a manner akin to technological innovation that replaces the work of low-skilled laborers (Feenstra, 2008). Instead of mechanizing these workers' labor, offshoring sends it abroad. Under this hypothesis, demand for less-skilled workers will fall, and their employment and wages will decline relative to employment and wages for highly skilled workers.

Substantial evidence supports this idea. Studies have related changes in industry-specific measures of offshoring, sometimes restricted to the imports of intermediates from some definition of low-wage countries, to either the wage- or employment-share of skilled workers. In survey of empirical work, Crinò (2009) finds that, across more than 25 articles studying 11 firms and industries in high-wage countries, including the U.S., Canada, UK, France, and Germany, offshoring to low-income economies is positively and significantly related to the share of employment or wages (or both) of highly-skilled workers in high-wage countries. This result is strongest for studies examining arms-length imports; it exists but is weaker in studies that model the effects of intra-MNC production transfer, as distinct from broader trade flows (ibid). Nonetheless, Harrison and McMillan (2011) show that the employment outcomes associated with such transfers have employment impacts, and these impacts differ depending on whether the production is being transferred to high- or low-income country affiliates. Specifically, the authors find that transfers to low-income affiliates is associated with job losses in the U.S. While this is not an uncontroversial finding, few studies in this area have had access to detailed worker characteristics that would permit a sense of the kinds of jobs created or workers displaced. ${ }^{5}$ Among the few exceptions, Ebenstein et al. (2009) find that, while manufacturing wages are not strongly affected by offshoring to low-wage countries, across educational categories, wage

\footnotetext{
${ }^{5}$ The aggregate employment effects of MNC offshoring is a controversial subject, with effects ranging from positive (Brainard and Riker, 1997; Mankiw and Swagel, 2006; Navaretti et al., 2010), negative (Harrison and McMillan, 2006, 2011) and none (Braconier and Ekholm, 2000).
} 
effects for workers who leave their manufacturing jobs are high.

Direct links between imports or offshoring and job loss have been less well studied. Looking at U.S. manufacturing industries over the period 1977-1987, Revenga (1992) finds that trade shocks, in the form of import price changes, chiefly affect employment not wages, suggesting that worker displacement is an important by-product of international trade. Kletzer (2000, 2001) uses Displaced Worker Surveys to show that job losses due to plant closures, mass layoffs or other non-performance reasons are positively linked to import competition, though not to trade in intermediates. Several other studies confirm this positive relationship between import competition and displacement (Haveman, 1994; Addison et al., 2000). These are all industrylevel results, however - they do not account for individual differences, especially skill.

A handful of recent studies have followed up on this work, mostly examining the likelihood of specific, short-run labor-market transitions between sectors, and from employment to unemployment. The variable of interest in these studies has chiefly been trade in intermediates. Among the strengths of this work is the use of individual-level data that account for bias due to compositional changes, as well as various sources of unobserved heterogeneity. For instance, Egger et al. (2007) follows 38,000 Austrian males, and finds that various measures of offshoring and import competition are negatively related over the short run to the likelihood of an individual staying in his job in an industry in which Austria does not hold a comparative advantage. Munch (2010) considers year-to-year transitions directly from manufacturing employment to unemployment, and finds a modest positive relationship between intermediate-goods imports and job loss for low-skill workers. Bachmann and Braun (2011) find similar results for Germany. By contrast, Geishecker (2008) exploits monthly worker data, finding that job tenure, not skill, is the chief determinant of German workers' job security.

Several other studies look beyond intermediates trade to focus on job loss due to other forms of internationalization. For instance, Becker and Muendler (2008) find that multinationals' foreign expansions do not reduce home-country job security, as compared with similar nonmultinational firms. Meanwhile, (Hummels et al., 2011) find that firm-specific importing shocks reduce wages and employment for Danish workers with only a high school education. MenezesFilho and Muendler (2011) examine the effects of tariff reductions in Brazil, and conclude that they are positively related to manufacturing job losses, often resulting in worker transitions to services and longer-term unemployment. And Autor et al. (2012b) examine the long-run impacts of Chinese import competition on U.S. manufacturing workers, finding that workers in sectors with high levels of Chinese export exposure spend less time at their initial employer and in their initial industry.

This paper adds to the scholarship linking trade and job loss in a few specific ways. First, it focuses explicitly on trade relationships with low-wage countries, which is where we would expect the clearest factor-proportions-type effects. Second, it takes a broader focus beyond intermediates, to examine low-wage import competition from all sources. Third, it accounts not just for relevant individual characteristics, but also for firm-specific factors that can bear upon job loss. Of particular importance is our inclusion of measures of technology investment, which could play a considerable and perhaps overlapping role with trade. Fourth, rather than focusing on aggregate firm or industry job losses, this paper differentiates results by skill level, 
focusing on workers with at least Bachelor's degree, and those with less than a high school diploma. Last, like Autor et al. (2012b) but unlike most of recent research in this area, it focuses on the links between trade and job in the United States.

\section{Trends in Low-Wage Import Competition}

To describe low-wage import competition, we rely on a measure proposed by Bernard et al. (2006), defined as follows: ${ }^{6}$

$$
L W I C O M P_{i t}=\frac{M_{i t}^{L}}{M_{i t}+P_{i t}-E_{i t}}
$$

where $M_{i t}^{L}$ and $M_{i t}$ are the value of imports in industry $i$ and time $t$ for low-wage countries $L$ and all countries, respectively; $P$ represents total domestic production, or shipments; and $E$ measures U.S. exports. As Bernard et al. (ibid) observe, low-wage import competition is therefore a function of the share of low-wage imports in the total value of industry imports, and overall import penetration. Equation (1) can also be modified to describe sector-specific levels of import competition from countries that are expected to pay higher wages, substituting the existing numerator for $\left(M_{i t}-M_{i t}^{L}\right)$.

Nonetheless, our primary interest in this paper is exploring impacts of trade with China and other low-wage economies. Countries are classified as low-wage on the basis of the World Bank country classification scheme, which annually slots national economies into four groups: low income; lower middle income; upper middle income; and high income. We use 1992, the first year available in our data, as the base classification year, and define the group of low-wage countries in terms of membership in the low income group. Effectively, this means that the group of low-wage countries had Gross National Incomes (GNI) per capita in 1992 of less than or equal to US $\$ 545 .^{7}$ Table 1 lists the 51 economies that fall into this category, that include China and India.

[Table 1 about here.]

[Figure 1 about here.]

We calculate $L W I C O M P$ by combining data from two U.S. Census Bureau data sources. Trade information comes from the Foreign Trade Imports and Exports data, which capture the universe of firms operating in the U.S. that import goods from abroad, compiled using information gathered by U.S. Customs and Border Protection. Products in these data are identified using ten-digit Harmonized System (HS) codes, with records going back to 1992. Using a crosswalk produced by Pierce and Schott (2012), we aggregate from the ten-digit HS product level to as many as 472 six-digit North American Industry Classification System (NAICS) manufacturing industries. ${ }^{8}$ Data on domestic production come from the Census of Manufactures

\footnotetext{
${ }^{6}$, Autor et al. (2012b) modifies this measure somewhat to account for dynamics.

${ }^{7}$ GNI per capital calculated using the World Bank's Atlas methodology. For details, see http://data.worldbank.org/indicator/NY.GNP.PCAP.CD

${ }^{8}$ Manufacturing is defined as those NAICS codes between 31-33.
} 
$(\mathrm{CM})$. These survey data are gathered in each year ending in 2 or 7 , and cover nearly all the private manufacturing activity in the United States. To conform with our trade data, we settle on four waves of the CM: 1992; 1997; 2002; and 2007. This results in a dataset that begins as low-wage imports start their rapid ascent, and ends just before the start of the Great Recession. ${ }^{9}$

Figure 1 presents the growth of import competition from low-wage and non-low-wage countries, with industry-level measures weighted by import shares. Between 1992 and 2007, import competition from low-wage economies has grown by more than $400 \%$, while from countries that are not classified as low-wage, it has expanded by one third. In absolute terms, import competition from higher-wage countries remains considerably higher than for low-wage economies, but as evidenced by differences in growth rates, this gap is closing.

[Table 2 about here.]

Table 2 presents more detailed descriptive evidence of the rising importance of U.S. imports from these low-wage economies. In the leftmost columns, for each of the 21 two-digit NAICS codes that comprise manufacturing, the table describes five-year changes in the share of lowwage imports in total imports. In the middle columns, at those same five-year intervals, it presents the results of equation (1) constructed at the two-digit NAICS level. The rightmost columns present absolute changes in employment and the percentage change in employment. Means and standard deviations for manufacturing on the whole are provided in the bottom rows. From Table 2, several broad points are evident. First, manufacturing industries vary in their exposure to trade from low-wage economies. In 2007, for instance, Beverage and Tobacco imports from low-wage economies accounted for only one percent of all U.S. imports, while they accounted for 74 percent of all imports in the Leather sector. At the same time, the table shows that low-wage imports in nearly all manufacturing industries have risen over the 15-year study period. The import competition measure $L W I C O M P$ shows both this variation and the common rising trend. Having a high share of low-wage imports plays a role in determining levels of import competition, but considerable variation exists, due to differences in the importance of trade in domestically-consumed production, the other component of LWICOMP. Additionally, while most manufacturing sectors have shed considerable fractions of their labor force, with a 24 percent decline overall, some of the largest declines in employment are found in industries facing substantial low-wage import competition. Apparel, for instance, has current labor force that is only a quarter of its level in 1992. Some computer component manufacturing has also experienced both high levels of low-wage import competition and considerable employment losses. Meanwhile, sectors like Food and Fabricated Metals have not experienced large declines in employment, with small absolute amounts of import competition (though, in each case there has been some growth). Clearly, low-wage imports are not the only factor shaping domestic employment dynamics, but from this table it is plausible that they have played a nontrivial

\footnotetext{
${ }^{9}$ Plants in the $1992 \mathrm{CM}$ are classified using the prior Standard Industrial Classification (SIC) system. To assign NAICS codes to these establishments, we take three steps. First, for continuing plants, we assign 1997 NAICS codes to 1992 iterations. Second, for non continuing plants, we use the standard Census SIC-NAICS crosswalk. Any unassigned plants after these two procedures are compared to the list of establishments in LEHD's Longitudinal Business Dynamics Bridge. Any matching firms are assigned corresponding NAICS codes. These three procedures account for over 90\% 1992 plants.
} 
role. We now turn to the more systematic examination of this relationship that is the focus of this paper.

\section{Empirical Approach}

The aim of this paper is to measure the extent to which low-wage import competition is related to job loss for more- and less-skilled workers. Specifically, we define a binary outcome capturing whether an individual loses his or her job between two time periods, and relate this to industryspecific low-wage import competition. To pursue this strategy, we fit two kinds of models. In the first, we relate job loss between periods $t$ and $t+1$ to levels of import competition in $t$,

$$
J_{o b l o s s}^{t \rightarrow t+t+1}=\beta_{0}+\beta_{1} L W I C O M P_{i t}+\beta_{2} X_{i j t}^{\prime}+\beta_{3} Z_{i k t}^{\prime}+\delta_{i}+\delta_{t}+\delta_{g}+\varepsilon_{j t}
$$

where $X^{\prime}$ is a vector of worker characteristics, including age, sex, nativity, and race, for worker $j$ with skill level $s$ working in industry $i$; $Z^{\prime}$ includes features of establishment $k$, notably computer investment. $\delta_{i}$ is an industry fixed effect that accounts for sector-specific characteristics unrelated to import competition; $\delta_{t}$ is a year dummy variable that captures business cycle dynamics; $\delta_{g}$ absorbs shocks that are state-specific; and $\varepsilon$ is an error term that satisfies classical regression assumptions. We believe that the lagged structure of our model, with prior levels of import competition affecting employment decisions over the next five years, is warranted on the basis that trade adjustment will not occur instantaneously.

The second model is similar to the first, but exploits temporal variation within industries and establishments. Specifically, we adopt a fixed effects panel approach, with job loss between periods $t+1$ and $t+2$ related to changes in import competition, along with changes in plantand firm-specific dynamics between $t$ and $t+1$, as follows:

$$
\text { Jobloss }_{i j s}^{t+1 \rightarrow t+2}=\beta_{0}+\beta_{1} L W I C O M P_{i, t \rightarrow t+1}+\beta_{2} Z_{i k, t \rightarrow t+1}^{\prime}+\delta_{i}+\delta_{t}+\delta_{s}+\varepsilon_{j t}
$$

In theory, equation (3) could include worker characteristics; in practice, no time-varying individual demographics are available in our data. The chief advantage of this model is the control for worker-level unobserved heterogeneity that is constant over time. This is particularly important, given that unobserved (but likely fairly stationary) differences in ability, motivation, attitude, teamwork could significantly affect the likelihood of retaining one's job.

In both approaches, the variable of interest is LWICOMP. In equation (2), a coefficient for $\beta_{1}$ greater than zero indicates that higher levels of low-wage import competition raise the likelihood of job loss for workers in a particular skill category. For equation (3), positive values for $\beta_{1}$ indicate that growth in import competition raises the likelihood of job loss.

Across these specifications, results obtained using LWICOMP could be biased to the extent that this variable is correlated with sector-specific changes in U.S. demand or productivity. Though our motivation is to explore how rising imports from China and other low-wage economies are affecting job loss for workers with different skills, our results could instead reflect unobserved factors that have more to do with internal U.S. industrial dynamics than with lowwage imports themselves. To account for this potential endogeneity bias, we instrument for our measure of import competition using two variables. The first captures the industry- and yearspecific value of exports from the same group of low-wage economies to countries in the EU-15, 
calculated using United Nations COMTRADE data. Assuming that other high-wage countries will face similar exposure to low-wage import competition when imports reflect factors inherent in low-wage economies, and that local demand-side shocks ought to be relatively uncorrelated across countries, this instrument ought to be helpful in providing estimates of the exogenous contribution of low-wage import competition to job loss. In order to produce test statistics of instrument exogeneity that require more instruments than potentially endogenous regressors, we also use a second instrument: an industry-year measure of trade costs, which is the sum of ad valorem tariff and freight rates, constructed by Bernard et al. (2006). ${ }^{10}$

Worker-level data for the analysis come from the Census Bureau's Longitudinal EmployerHousehold Dynamics (LEHD). The LEHD program integrates administrative records from statespecific unemployment insurance (UI) programs with Census Bureau economic and demographic data. LEHD offers a number of crucial advantages over surveys of displaced workers. First, it tracks workers as they flow from job to job, combining them with characteristics of the establishments at which they work. Second, with only minor exceptions, the data cover the universe of workers in participating states. Jobs covered by UI include $90 \%$ of total wage and salary jobs in the civilian sector of the U.S. economy (Stevens, 2002; McKinney and Vilhuber, 2011). ${ }^{11}$ The 30 states available to researchers in Census Bureau Research Data Centers through the LEHD program at the time this research project was approved include populous states like California, Florida, Texas, and Illinois; together they constitute $65 \%$ percent of the total U.S. workforce. These and other states in which LEHD data is available, such as Georgia, North Carolina and Wisconsin are also among the largest states in terms of manufacturing employment and shipments.

One limitation of LEHD is its scant information regarding establishments. We address this issue by combining LEHD with detailed plant data from the Census of Manufactures. This means we focus exclusively on individuals whose initial appearance in the LEHD data is in a job in a manufacturing establishment, though workers who transition from such employment to jobs in any sector remain in the analytical sample. Linking LEHD to the Census of Manufactures is a nontrivial task that necessitates a few accommodations. First, it requires a shift from LEHD's quarterly frequency to a quinquennial panel. Additionally, we aggregate from the plant level to the scale of unique State Employer Identification Numbers, or SEINs, which are state-specific unemployment-insurance taxpayer identifiers. An SEIN will correspond to an individual plant for organizations that operate only a single plant in a particular state, while for firms with multiple plants in the same state, it represents the aggregate of those establishments. Although this aggregation may mask some heterogeneity for some multi-plant employers, this level also offers two benefits. First, individual workers in LEHD cannot be directly assigned to individual establishments in the case of multi-plant firms. ${ }^{12}$ More importantly, match rates between plants

\footnotetext{
${ }^{10}$ In addition to Bernard et al. (2006), instruments like these have been used in other recent studies, including Autor et al. (2012b) and Hummels et al. (2011).

${ }^{11}$ Unemployment insurance records typically do not include many government workers; agricultural workers; and members of the armed forces.

${ }^{12}$ It is possible to assign workers to establishments using Census Bureau-created imputations, such that each employee in an organization that has multiple plants in the same state is assigned 10 possible plant matches. Hence, estimates could in theory be produced using imputation commands such as Stata's mi suite. Given the size the data, however, this approach creates computational challenges, since an imputation-ready dataset would effectively contain nearly ten times the original number of records.
} 
in the LEHD and Census of Manufactures improve dramatically when we restrict matching to state and Employer Identification Numbers (EINs). Effectively, our analytical sample is dramatically larger when matching on this basis. ${ }^{13}$

The addition of data from the Census of Manufactures means we can include a number of key plant-level predictors. Most importantly, we estimate establishment-specific technological change, by calculating investment in high technology, using the fraction of spending on computer equipment in total equipment expenditures. ${ }^{14}$ As discussed earlier, it is widely held that technological change has been the primary driver of labor market reallocation over the past decades. If computers and other high-technology investments function to substitute for workers with low skill levels, we should expect it to be positively related to job loss for those workers. Several additional establishment-level controls are included in estimates of equations (2) ands (3). We include a measure of total shipments to capture establishment size; the ratio of capital to value-added to account for overall differences in capital-intensity; a dummy variable that takes on a value of one when an establishment is part of a multi-unit firm; a measure of establishment exports, since research indicates that exporters and nonexporters behave differently (Bernard et al., 1995; Bernard and Jensen, 1999); and finally a measure of the age of the establishment. $^{15}$

We retain only workers between the ages of 16 and 65 who are employed at the same establishment for all four quarters and who do not simultaneously work at another job, and who appear in at least the subsequent wave of data, such that it may be possible to observe a change in their job status. Among these workers, job loss is defined as a change in employer between two consecutive periods, such that nominal salary in the second position is less than the salary a worker held in the first. This is a different approach toward identifying job loss than is common in the literature. In survey data, workers report being 'displaced' or 'dislocated' when their departure was involuntary, due to layoffs or plant closures, as distinct from being a function of individual performance (Kletzer, 1998). With administrative data like LEHD, it is not possible to determine definitively whether a departure from a job was voluntary or involuntary. However, it is unlikely that a transition from one full-year fully-employed job to another would be undertaken voluntarily if such a switch entailed losses in annual income. Moreover, a focus on the sample of workers who are more likely to be fully-employed also limits bias that might

\footnotetext{
${ }^{13}$ We match LEHD and the Census of Manufactures using two bridges: the Business Register Bridge (BRB) and the Longitudinal Business Dynamics Bridge (LBDB). This is required since BRB covers 1992, while LBDB tracks the period 1997 to 2004. We first adjust the BRB, assigning NAICS codes to EINs, using three methods in sequence: first we assign NAICS codes when there are 1:1 SIC-NAICS matches; second, for matches that are 1:many, we collect industry codes from subsequent appearances of the firm in LBDB; third, we assign NAICS codes to any remaining firms based on the most probable NAICS on the basis of employment ratios. This adjusted BRB is combined with LBDB to form a master bridge between LEHD and the Census of Manufactures. Due to LBDB's termination in 2004, we lose firms that appear only after this date. However, such firms would not be included in the analysis, given the temporal structure of equations (2) and (3). In terms of granularity, matching using state and industry results in more than a 60 percent match rate, while using the most restrictive matching, we retain only approximately 17 percent of the firms.

${ }^{14}$ Note that computer investment data are unavailable in 1997. We ran models excluding 1997 and subsequently using computer investment data for 1997 that we interpolated from surrounding observations. There were no qualitative differences in the results of our models; results presented are from the interpolated 1997 values of computer investment.

${ }^{15}$ For equation (2), we include a direct measure of plant age. For fixed effects estimates of equation (3), which do not allow time-invariant predictors, we create a 'relative plant age' indicator, which is the ratio of the first year of plant operations and the current year.
} 
arise if workers vary considerably in terms their labor-force attachment. For workers with less than a high school degree, designated as low-skill workers, this results in an analytical sample for equation (2) of 1,000,400, and a sample of 565,000 for equation (3). Samples for equation (3) are smaller because of the added restrictions it imposes in terms of continuity across multiple periods. For workers with at least a Bachelor's degree, constituting the high-skill subset of workers, the sample for equation (2) consists of 850,000 workers, while 550,000 college-educated workers are available to estimate equation (3). ${ }^{16}$ In samples for equation (2), 13.9 percent of workers with less than a high school degree lost their jobs over the study period; the comparable figure for workers with at least a Bachelor's degree is 14.4 percent.

\section{Results}

Equation (2) is a pooled cross-sectional model that can be estimated using both ordinary least squares as well as binomial logistic regression. ${ }^{17}$ Estimates produced using the logistic model are preferable, given the limited dependent variable. All models are estimated with standard errors clustered at the level of the establishment, on the basis that the likelihood of a worker losing their job to trade competition will be related to that of their co-workers. Three kinds of estimates of equation (2) are produced for low- and high-skill workers: ordinary least squares, logistic, and a two-stage least-squares regression. It is possible to estimate equation (3) using standard fixed effects and fixed effects logit models; all things equal the latter is preferable. However, panel logit models systematically failed to converge; despite a wealth of diagnostics, this problem could not be solved. Hence, a linear probability fixed effects model is presented, along with estimates produced using a fixed effects instrumental variables approach. Estimation using the linear probability model should not be biased, though it will be inefficient due to potential heteroscedasticity; however, the clustered standard errors should correct for this issue.

[Table 3 about here.]

\subsection{Low-skill workers}

For workers with less than a high school education, Table 3 reports estimates of the relationship between low-wage import competition and job loss. The first three columns report results from equation (2), in which levels of import competition at time $t$ predict the likelihood that a worker loses her job between $t$ and $t+1$. The first column presents estimates produced using ordinary least squares. For these and all other estimates, standard errors have been clustered at the level of the establishment, on the basis that one should expect an individual's likelihood of job loss to be related to that of her co-workers. ${ }^{18}$ Low-wage import competition, LWICOMP, is positively related to the outcome, suggesting that greater threat from low-wage imports is associated with greater risks of job loss for less-skilled workers; however the coefficient is not significant in

\footnotetext{
${ }^{16}$ These sample sizes have been rounded to the nearest 1,000 to facilitate disclosure through the U.S. Census Bureau's Center for Economic Studies.

${ }^{17}$ The latter implies a somewhat rewritten version of equation (2).

${ }^{18}$ Results were also produced using simple heteroscedasticity-robust standard errors. The broad contours of the results did not vary dramatically, however import competition was positive and significant across all estimators. These results are available upon request
} 
this specification. Interestingly, computer investment is negatively and significantly related to job loss for this group of workers. The higher the share of computer equipment in total investment, the lower the likelihood of a low-skill worker losing one's job. Job loss is also negatively related to firm size, as measured by shipments, as well as to the ratio of capital to value-added. Being a low-skill worker in a multi-unit firm increases the likelihood of job loss; exporting is also positively related to job loss, though insignificantly in this model. Among demographic characteristics, older workers and female workers are more likely to lose their jobs, while immigrants and white workers face lower odds of job loss. This same pattern of results holds for the second column, that estimates a logistic regression that ought to be more efficient, given the limited dependent variable.

In the third column, we account for potential endogeneity bias by instrumenting for LWICOMP using both exports from our sample of low-wage countries to EU-15 economies, and the measure of trade costs, each time- and six-digit NAICS industry-specific. We report several diagnostics on the suitability of these instruments. The Kleibergen-Paap $F$-statistic reports on instrument strength under the assumption that errors are not independent and identically distributed. The value of 202.13 is well above the Stock-Yogo critical values, from which we conclude that the instrument set is not weak. The Hansen- $J p$-value means that we fail to reject the hypothesis that the instruments are not exogenous. In other words, we can assume that our instruments are not correlated with the error term, permitting us to estimate the exogenous contribution of low-wage import competition to job loss. The second-stage results shown in column 3 are closely related to results in the first two columns, except that the coefficient on low-wage import competition, still positive, is now highly significant.

\section{[Table 4 about here.]}

The fourth and fifth columns report results from equation (3), in which we better exploit the dynamics available in the data. In these estimates, changes in import competition between $t$ and $t+1$ are related to the likelihood of losing one's job between $t+1$ and $t+1$. As described above, these models are fitted using the fixed effects estimator, whose chief benefit in this context is to account for any time-invariant individual unobserved heterogeneity. We therefore expect these estimates to better reflect our relationship of interest. Worker demographics are not included in the model, since these are time invariant (or in the case of worker age or job tenure, they change in lockstep with years, which we capture with a year dummy variable). Column 4 presents results that broadly resemble those from the other low-skill models. Lowwage import competition is positively and significantly related to job loss. Exporting enters as negative and significant, suggesting that growth in exports reduces the likelihood of job loss for low-skill workers. Neither multi-unit status nor plant age are significantly related to job loss in this model. In column 5 we present results produced using a two-stage least-squares fixed effects estimator. $F$-statistic and Hansen $J$ values again suggest that the instrument set is not weak and can be considered exogenous. Results are in line with those produced using the standard fixed effects estimator, with import competition positively and significantly related to job loss, while the coefficient on computer investment is negative and significant. 


\subsection{High-skill workers}

The second worker subgroup of interest is high-skill workers, defined as those who have obtained at least a Bachelor's degree. We follow the same sequence of models as for low-skill workers, beginning with models that predict job loss as a function of levels of import competition, before shifting to models that estimate how changes in import competition influence the odds of job loss. Columns 1 and 2 present results produced using OLS and Logit estimators. In both cases, import competition is not significantly related to job loss for this worker subgroup. Computer investment remains negative and significant: all else equal, highly skilled workers have more job security in establishments that invest relatively more on computer equipment. This negative relationship is true for overall capital investment as well. Highly-skilled workers face greater odds of job loss in smaller and younger establishments, as well as in establishments that are part of multiunit firms. Exports appear to be unrelated to job loss in these initial models. The same patterns remain in the 2SLS model in column 3, except that import competition is positive and weakly significant (at the 10 percent level).

The fourth and fifth columns again present results in which changes in import competition over a prior period predict potential job loss over a subsequent period. Results are broadly consistent with those obtained using equation (2). Most importantly, for highly skilled workers, import competition appears to be unrelated to the likelihood of losing one's job. Meanwhile, computer investments appear to reduce the odds of job loss. Exports are now negatively and significantly related to job loss, as is plant age. Instruments in the fixed effects instrumental variables estimates are not weak, and pass the test of orthogonality.

\section{Conclusion}

U.S. imports of manufactured goods from China and other developing countries have risen dramatically over the last several decades, while domestic manufacturing employment has contracted from a peak of over 30 percent to less than 10 percent today. The goal of this paper has been to consider the impact of industry-specific low-wage import competition on the likelihood of losing one's manufacturing job. We have been particularly interested in examining how the risks of job loss may be disproportionately born by workers who have lower skill levels, as one would expect from contemporary 'horizontal' and 'vertical' updates of the neoclassical theory of factor proportions. We consider the links between trade and job loss while also accounting for potential roles for individual and establishment characteristics, especially computerization.

Our primary finding is that low-wage imports have a different relationship to job loss depending on a worker's skill level. We find low-wage import competition raises the likelihood of job loss among manufacturing workers who have completed less than a full high school education. Controlling for worker characteristics, as well as features of the establishments where they work, low-skill workers are more likely to lose their jobs when they work in sectors with higher initial levels of low-wage import competition, as well as industries where this import competition has grown over the preceding period. By contrast, among workers who have completed at least a Bachelor's degree, industry-specific pressure from low-wage imports appears to be largely unrelated to the likelihood of job loss. Over the period 1992 to 2007, these high-skill 
U.S. manufacturing workers appear to be sheltered from the effects of China's rise.

Technology is typically considered to be a major, if not the most important driver of labor reallocation, and it has been considered to operate in a skill-biased manner. We do not find a skill-biased link between technology and job loss. Across both high- and low-skill workers, establishment-specific investments in computer equipment are associated with job retention. This is a challenging finding, since a great deal of theory suggests that computers are substitutes for less-skilled workers. As expected, in both worker groups, larger, older and more capitaland export-intensive establishments are associated with lower odds of job loss, though these relationships are not statistically significant in all models.

Contrary to a great deal of the literature on the labor market impacts of globalization, this paper's findings suggest that imports from low-wage economies have adversely affected labor market outcomes for low-skill workers. Consistent with factor proportions, import competition from countries whose comparative advantage lie in low-skilled labor has meant that less-skilled workers in the U.S. have had less job security. The positive association between imports and the risk of job loss for less-skilled workers may well represent a lower bound, since our focus on workers who are full-year and singularly employed ignores part-time workers and others with lower levels of labor market attachment. It is not implausible that these workers may be more vulnerable to the effects of import competition, moreover they are also likely to be better represented among less-skilled workers. Less-skilled manufacturing workers on the whole, in other words, may be more vulnerable than suggested by this study. It should be said that these results say nothing about the overall gains from trade, which may well outweigh losses in this worker group. However, it provides further evidence that trade has played some role in the poor recent labor market situation of these domestic workers, and likely in the larger expansion of income inequality. 


\section{References}

Addison, J. T., Fox, D. A., and Ruhm, C. J. (2000). Technology, trade sensitivity, and labor displacement. Southern Economic Journal, pages 682-699.

Antràs, P., Garicano, L., and Rossi-Hansberg, E. (2006). Offshoring in a knowledge economy. The Quarterly Journal of Economics, 121(1):31-77.

Autor, D., Dorn, D., and Hanson, G. H. (2012a). The China Syndrome: Local labor market effects of import competition in the United States. National Bureau of Economic Research Working Paper 18054.

Autor, D., Dorn, D., Hanson, G. H., and Song, J. (2012b). Trade adjustment: Worker level evidence.

Autor, D., Katz, L., and Kearney, M. (2008). Trends in US wage inequality: Revising the revisionists. The Review of Economics and Statistics, 90(2):300-323.

Bachmann, R. and Braun, S. (2011). The impact of international outsourcing on labour market dynamics in germany. Scottish Journal of Political Economy, 58(1):1-28.

Baldwin, R. (2006). Globalisation: the great unbundling(s). Finnish Prime Minister's Office for EU Presidency.

Becker, S. O. and Muendler, M.-A. (2008). The effect of fdi on job security. The BE Journal of Economic Analysis 83 Policy, 8(1).

Bernard, A. and Jensen, J. (1999). Exceptional exporter performance: cause, effect, or both? Journal of International Economics, 47(1):1-25.

Bernard, A. B., Jensen, J. B., and Lawrence, R. Z. (1995). Exporters, jobs, and wages in us manufacturing: 1976-1987. Brookings Papers on Economic Activity. Microeconomics, 1995:67119.

Bernard, A. B., Jensen, J. B., and Schott, P. K. (2006). Survival of the best fit: Exposure to lowwage countries and the (uneven) growth of us manufacturing plants. Journal of International Economics, 68(1):219-237.

Bernard, A. B., Redding, S. J., and Schott, P. K. (2010). Multiple-product firms and product switching. American Economic Review, 100(1):70-97.

Blinder, A. (2006). Offshoring: The Next Industrial Revolution. Foreign Affairs, 85(2):113-128.

Braconier, H. and Ekholm, K. (2000). Swedish multinationals and competition from high-and low-wage locations. Review of International Economics, 8(3):448-461.

Brainard, S. L. and Riker, D. A. (1997). Are us multinationals exporting us jobs? Technical report, National Bureau of Economic Research.

Crinò, R. (2009). Offshoring, multinationals and labour market: a review of the empirical literature. Journal of Economic Surveys, 23(2):197-249.

Ebenstein, A., Harrison, A., McMillan, M., Phillips, S., and Hall, G. (2009). Estimating the Impact of Trade and Offshoring on American Workers Using the Current Population Surveys. NBER Working Paper.

Edwards, L. and Lawrence, R. Z. (2013). Rising Tide: Is Growth in Emerging Economies Good for the United States? Peterson Institute for International Economics. 
Egger, P., Pfaffermayr, M., and Weber, A. (2007). Sectoral adjustment of employment to shifts in outsourcing and trade: evidence from a dynamic fixed effects multinomial logit model. Journal of applied Econometrics, 22(3):559-580.

Feenstra, R. (2008). Offshoring in the Global Economy (The Ohlin Lectures 2008). Stockholm School of Economics.

Feenstra, R. and Hanson, G. (2001). Global production sharing and rising inequality: A survey of trade and wages. NBER working paper.

Feenstra, R. C. (2010). Offshoring in the global economy: microeconomic structure and macroeconomic implications. Cambridge Univ Press.

Freeman, R. B. (1995). Are your wages set in beijing? The Journal of Economic Perspectives, $9(3): 15-32$.

Geishecker, I. (2008). The impact of international outsourcing on individual employment security: A micro-level analysis. Labour Economics, 15(3):291-314.

Goos, M. and Manning, A. (2007). Lousy and lovely jobs: The rising polarization of work in Britain. The Review of Economics and Statistics, 89(1):118-133.

Grossman, G. M. and Rossi-Hansberg, E. (2006). The rise of offshoring: its not wine for cloth anymore. The New Economic Geography: Effects and Policy Implications, pages 59-102.

Grossman, G. M. and Rossi-Hansberg, E. (2008). Trading tasks: A simple theory of offshoring. American Economic Review, 98(5):1978.

Harrison, A. and McMillan, M. (2011). Offshoring jobs? multinationals and us manufacturing employment. Review of Economics and Statistics, 93(3):857-875.

Harrison, A. E. and McMillan, M. S. (2006). Dispelling some myths about offshoring. The Academy of Management Perspectives, 20(4):6-22.

Haskel, J. and Slaughter, M. (2001). Trade, technology and UK wage inequality. The Economic Journal, 111(468):163-187.

Haskel, J. and Slaughter, M. (2002). Does the sector bias of skill-biased technical change explain changing skill premia? European Economic Review, 46(10):1757-1783.

Haveman, J. (1994). The influence of changing trade patterns of displacements of labor. Purdue University, Center for International Business Education and Research (CIBER).

Helpman, E., Itskhoki, O., and Redding, S. (2010). Inequality and unemployment in a global economy. Econometrica, 78(4):1239-1283.

Hummels, D., Jorgensen, R., Munch, J., and Xiang, C. (2011). The wage and employment effects of offshoring: Evidence from danish matched worker-firm data.

Kletzer, L. G. (1998). Job displacement. The Journal of Economic Perspectives, 12(1):115-136.

Kletzer, L. G. (2000). Trade and job loss in us. manufacturing, 1979-1994. In The Impact of International Trade on Wages, pages 349-396. University of Chicago Press.

Kletzer, L. G. (2001). Job loss from imports: measuring the costs. Peterson Institute.

Krugman, P. R. (2008). Trade and wages, reconsidered. Brookings Papers on Economic Activity, 2008(1):103-154. 
Lawrence, R., Slaughter, M., Hall, R., Davis, S., and Topel, R. (1993). International trade and American wages in the 1980s: giant sucking sound or small hiccup? Brookings Papers on Economic Activity. Microeconomics, 1993(2):161-226.

Levy, F. and Murnane, R. (2004). The new division of labor: How computers are creating the next job market. Princeton University Press.

Liu, R. and Trefler, D. (2008). Much ado about nothing: American jobs and the rise of service outsourcing to China and India. NBER Working Paper.

Mankiw, G. and Swagel, P. (2006). The politics and economics of offshore outsourcing. Journal of Monetary Economics, 53(5):1027-1056.

McKinney, K. and Vilhuber, L. (2011). LEHD infrastructure guiles in the census RDC: Overview of S2004 snapshot. U.S. Census Bureau Center for Economic Studies Working Paper 11-13.

Melitz, M. J. (2003). The impact of trade on intra-industry reallocations and aggregate industry productivity. Econometrica, 71(6):1695-1725.

Menezes-Filho, N. A. and Muendler, M.-A. (2011). Labor reallocation in response to trade reform. National Bureau of Economic Research Working Paper 17372.

Munch, J. R. (2010). Whose job goes abroad? international outsourcing and individual job separations. The Scandinavian Journal of Economics, 112(2):339-360.

Navaretti, G. B., Castellani, D., and Disdier, A.-C. (2010). How does investing in cheap labour countries affect performance at home? firm-level evidence from france and italy. Oxford Economic Papers, 62(2):234-260.

Pierce, J. R. and Schott, P. K. (2012). A concordance between ten-digit us harmonized system codes and sic/naics product classes and industries. Journal of Economic and Social Measurement, 37(1):61-96.

Revenga, A. L. (1992). Exporting jobs? the impact of import competition on employment and wages in us manufacturing. The Quarterly Journal of Economics, 107(1):255-284.

Stevens, D. (2002). Employment that is not covered by state unemployment insurance laws. U.S. Census Bureau Longitudinal Employer - Household Dynamics Technical paper No. TP2002-16.

Verhoogen, E. A. (2008). Trade, quality upgrading, and wage inequality in the mexican manufacturing sector. The Quarterly Journal of Economics, 123(2):489-530.

Yeaple, S. R. (2005). A simple model of firm heterogeneity, international trade, and wages. Journal of international Economics, 65(1):1-20. 


\section{List of Figures}

1 The Rise of Low-Wage Import Competition . . . . . . . . . . . . . . . . 20 
Figure 1: The Rise of Low-Wage Import Competition

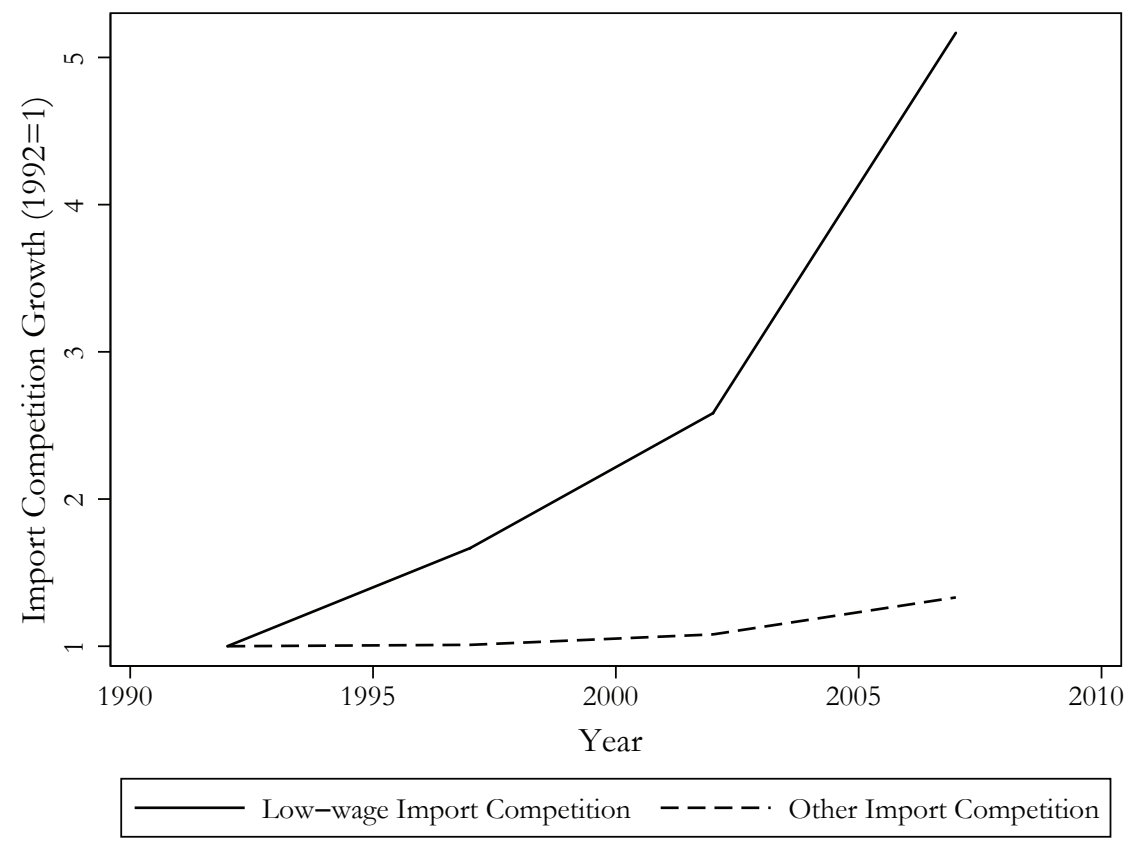




\section{List of Tables}

1 Low-Wage Countries . . . . . . . . . . . . . . . . . . . . . . . 22

2 Low Wage Import Competition Across U.S. Manufacturing Industries . . . . . . 23

3 Low-Wage Import Competition and Job Loss Among Workers with a High School Degree Or Less . . . . . . . . . . . . . . . . . . . . . . . . . 24

4 Low-Wage Import Competition and Job Loss Among Workers with a Bachelor's Degree or More . . . . . . . . . . . . . . . . . . . 25 
Table 1: Low-Wage Countries

\begin{tabular}{lllll}
\hline Afghanistan & Comoros & Haiti & Maldives & Sao Tome \\
Bangladesh & Congo & Honduras & Mali & Sierra Leone \\
Bhutan & Egypt & India & Mauritania & Solomon Isl. \\
Benin & Equatorial Guinea & Indonesia & Mozambique & Somalia \\
Burkina Faso & Ethiopia & Kenya & Myanmar & Sri Lanka \\
Burundi & Gambia & Laos & Nepal & Sudan \\
Cambodia & Ghana & Lesotho & Niger & Tanzania \\
Central African Rep. & Guinea & Liberia & Nigeria & Togo \\
Chad & Guinea-Bissau & Madagascar & Pakistan & Uganda \\
China & Guyana & Malawi & Rwanda & Vietnam \\
& & & & Zambia \\
\hline
\end{tabular}

Note: Classified according to the World Bank for the year 1992. N=51 
Table 2: Low Wage Import Competition Across U.S. Manufacturing Industries

\begin{tabular}{|c|c|c|c|c|c|c|c|c|c|c|}
\hline \multirow[b]{2}{*}{ Industry } & \multicolumn{4}{|c|}{ Low-wage Imports in Total (\%) } & \multicolumn{4}{|c|}{$L W I C O M P$} & \multirow{2}{*}{$\begin{array}{c}\text { Empl } \\
\Delta\end{array}$} & \multirow{2}{*}{$\begin{array}{c}\text { Empl } \\
\Delta(\%)\end{array}$} \\
\hline & 1992 & 1997 & 2002 & 2007 & 1992 & 1997 & 2002 & 2007 & & \\
\hline Food & 6 & 9 & 8 & 13 & 0.4 & 0.5 & 0.5 & 1.1 & -23.2 & -1.5 \\
\hline Beverage \& Tobacco & 1 & 2 & 2 & 1 & 0.0 & 0.2 & 0.2 & 0.2 & -118.9 & -33.9 \\
\hline Textile Mills & 16 & 19 & 20 & 27 & 3.2 & 3.5 & 5.2 & 8.5 & -322.1 & -65.5 \\
\hline Textile Prod. Mills & 44 & 45 & 53 & 73 & 8.6 & 7.7 & 14.1 & 32.8 & -77.9 & -33.1 \\
\hline Apparel & 31 & 36 & 39 & 67 & 16.4 & 21.0 & 28.2 & 57.5 & -688.2 & -76.2 \\
\hline Leather & 40 & 57 & 66 & 74 & 28.2 & 42.3 & 58.4 & 70.3 & & \\
\hline Wood & 10 & 8 & 10 & 20 & 1.7 & 1.6 & 2.1 & 3.8 & -25.9 & -4.8 \\
\hline Paper & 1 & 3 & 6 & 13 & 0.2 & 0.4 & 0.9 & 2.1 & -189.0 & -29.2 \\
\hline Printing \& Related & 10 & 11 & 22 & 36 & 2.2 & 1.7 & 5.3 & 14.2 & -186.5 & -23.1 \\
\hline Petroleum \& Coal & 4 & 9 & 4 & 3 & 0.4 & 1.3 & 0.8 & 0.6 & -38.3 & -25.1 \\
\hline Chemicals & 2 & 4 & 4 & 6 & 0.4 & 0.7 & 0.9 & 1.8 & -174.8 & -16.9 \\
\hline Plastics \& Rubber & 7 & 15 & 20 & 31 & 0.8 & 1.6 & 2.8 & 6.1 & -67.6 & -8.2 \\
\hline Nonmetallic Minerals & 8 & 16 & 24 & 30 & 1.4 & 2.6 & 4.5 & 6.3 & -27.9 & -5.3 \\
\hline Primary Metals & 2 & 3 & 5 & 10 & 0.6 & 0.8 & 1.4 & 3.8 & -232.8 & -33.8 \\
\hline Fabricated Metals & 7 & 11 & 19 & 29 & 1.1 & 1.6 & 3.5 & 6.9 & -47.2 & -2.9 \\
\hline Machinery & 2 & 5 & 9 & 16 & 0.6 & 1.4 & 2.8 & 6.4 & -222.7 & -15.8 \\
\hline Computer \& Electric & 4 & 8 & 17 & 36 & 2.1 & 3.6 & 9.3 & 23.1 & -630.0 & -33.1 \\
\hline Electrical Equipment & 11 & 19 & 28 & 34 & 2.9 & 5.3 & 10.1 & 16.5 & -203.7 & -32.2 \\
\hline Transport Equipment & 0 & 1 & 1 & 3 & 0.1 & 0.2 & 0.5 & 1.7 & -422.6 & -19.8 \\
\hline Furniture & 9 & 22 & 43 & 62 & 1.5 & 4.0 & 11.1 & 19.9 & -72.3 & -12.0 \\
\hline Miscellaneous & 24 & 36 & 41 & 48 & 10.5 & 14.4 & 17.7 & 26.0 & -44.0 & -6.4 \\
\hline Mean & 11 & 16 & 21 & 30 & 4 & 6 & 9 & 15 & -191 & -24 \\
\hline Standard Deviation & 13 & 15 & 18 & 23 & 7 & 10 & 13 & 19 & 193 & 20 \\
\hline
\end{tabular}

Note: Employment change and growth rates based on authors' calculations using BLS data between 1992 and 2007. Trade and import competition based on authors' calculation using Foreign Trade Imports and Exports data as well as data from the Census of Manufactures. Low wage countries are defined as being those defined as "Low-income' in 1992, according to the World Bank's country classifications. 
Table 3: Low-Wage Import Competition and Job Loss Among Workers with a High School Degree Or Less

Outcome: Job Loss $(0=$ Kept Job; $1=$ Lost Job)

\begin{tabular}{|c|c|c|c|c|c|}
\hline & $\begin{array}{c}(1) \\
\text { OLS }\end{array}$ & $\begin{array}{c}(2) \\
\text { Logit }\end{array}$ & $\begin{array}{c}(3) \\
2 \text { SLS }\end{array}$ & $\begin{array}{l}(4) \\
\mathrm{FE}\end{array}$ & $\begin{array}{c}(5) \\
\text { FE } 2 \text { SLS }\end{array}$ \\
\hline$L W I C O M P$ & $\begin{array}{c}0.0508 \\
(0.0370)\end{array}$ & $\begin{array}{c}0.4611 \\
(0.3336)\end{array}$ & $\begin{array}{c}0.2661 \\
(0.0955)^{* * *}\end{array}$ & $\begin{array}{c}0.1044 \\
(0.0622)^{*}\end{array}$ & $\begin{array}{c}0.4273 \\
(0.1656)^{* * *}\end{array}$ \\
\hline Computer Investment & $\begin{array}{c}-0.0284 \\
(0.0056)^{* * *}\end{array}$ & $\begin{array}{c}-0.2644 \\
(0.0578)^{* * *}\end{array}$ & $\begin{array}{c}-0.0289 \\
(0.0056)^{* * *}\end{array}$ & $\begin{array}{c}-0.0727 \\
(0.0130)^{* * *}\end{array}$ & $\begin{array}{c}-0.0744 \\
(0.0131)^{* * *}\end{array}$ \\
\hline Shipments (\$mil) & $\begin{array}{c}-0.0109 \\
(0.0033)^{* * *}\end{array}$ & $\begin{array}{c}-0.0931 \\
(0.0345)^{* * *}\end{array}$ & $\begin{array}{c}-0.0108 \\
(0.0033)^{* * *}\end{array}$ & $\begin{array}{c}-0.0200 \\
(0.0064)^{* * *}\end{array}$ & $\begin{array}{c}-0.0194 \\
(0.0060)^{* * *}\end{array}$ \\
\hline Capital/Value-Added & $\begin{array}{c}-0.0001 \\
(0.0001)^{* *}\end{array}$ & $\begin{array}{c}-0.0008 \\
(0.0002)^{* * *}\end{array}$ & $\begin{array}{c}-0.0001 \\
(0.0001)^{* *}\end{array}$ & $\begin{array}{c}-0.0002 \\
(0.0001)^{* * *}\end{array}$ & $\begin{array}{c}-0.0002 \\
(0.0001)^{* * *}\end{array}$ \\
\hline Multi-Unit Firm & $\begin{array}{c}0.0484 \\
(0.0022)^{* * *}\end{array}$ & $\begin{array}{c}0.4192 \\
(0.0181)^{* * *}\end{array}$ & $\begin{array}{c}0.0483 \\
(0.0022)^{* * *}\end{array}$ & $\begin{array}{c}0.0343 \\
(0.0218)\end{array}$ & $\begin{array}{c}0.0348 \\
(0.0220)\end{array}$ \\
\hline Exports $(\$$ mil $)$ & $\begin{array}{l}-0.0182 \\
(0.0187)\end{array}$ & $\begin{array}{l}-0.2290 \\
(0.2497)\end{array}$ & $\begin{array}{l}-0.0172 \\
(0.0187)\end{array}$ & $\begin{array}{c}-0.0893 \\
(0.0203)^{* * *}\end{array}$ & $\begin{array}{c}-0.0871 \\
(0.0193)^{* * *}\end{array}$ \\
\hline SEIN Age/Rel. Age & $\begin{array}{c}-0.0012 \\
(0.0002)^{* * *}\end{array}$ & $\begin{array}{c}-0.0101 \\
(0.0014)^{* * *}\end{array}$ & $\begin{array}{c}-0.0012 \\
(0.0002)^{* * *}\end{array}$ & $\begin{array}{l}-2.0235 \\
(1.7917)\end{array}$ & $\begin{array}{c}-2.0691 \\
(1.8050)\end{array}$ \\
\hline Worker Age & $\begin{array}{c}0.0009 \\
(0.0000)^{* * *}\end{array}$ & $\begin{array}{c}0.0077 \\
(0.0004)^{* * *}\end{array}$ & $\begin{array}{c}0.0009 \\
(0.0000)^{* * *}\end{array}$ & & \\
\hline Female & $\begin{array}{c}0.0092 \\
(0.0012)^{* * *}\end{array}$ & $\begin{array}{c}0.0764 \\
(0.0096)^{* * *}\end{array}$ & $\begin{array}{c}0.0093 \\
(0.0012)^{* * *}\end{array}$ & & \\
\hline Foreign Born & $\begin{array}{c}-0.0153 \\
(0.0017)^{* * *}\end{array}$ & $\begin{array}{c}-0.1315 \\
(0.0153)^{* * *}\end{array}$ & $\begin{array}{c}-0.0154 \\
(0.0017)^{* * *}\end{array}$ & & \\
\hline White & $\begin{array}{c}-0.0086 \\
(0.0014)^{* * *}\end{array}$ & $\begin{array}{c}-0.0717 \\
(0.0116)^{* * *}\end{array}$ & $\begin{array}{c}-0.0087 \\
(0.0014)^{* * *}\end{array}$ & & \\
\hline Year Fixed Effects & Yes & Yes & Yes & Yes & Yes \\
\hline Industry Fixed Effects & Yes & Yes & Yes & Yes & Yes \\
\hline State Fixed Effects & Yes & Yes & Yes & Yes & Yes \\
\hline Clustered SE @ SEIN & Yes & Yes & Yes & Yes & Yes \\
\hline Observations & $1,00,4000$ & $1,004,000$ & $1,004,000$ & 565,000 & 565,000 \\
\hline R-Squared & 0.02 & 0.03 & - & 0.13 & - \\
\hline$F$-statistic (K-P) & - & - & 202.13 & - & 95.6 \\
\hline Hansen $J$ & - & - & 0.021 & - & 0.778 \\
\hline Hansen $J p$-value & - & - & 0.884 & - & 0.3777 \\
\hline
\end{tabular}

Note: ${ }^{*}$ significant at $10 \% ;{ }^{* *}$ significant at $5 \% ;{ }^{* *}$ significant at $1 \%$ 
Table 4: Low-Wage Import Competition and Job Loss Among Workers with a Bachelor's Degree or More

\begin{tabular}{|c|c|c|c|c|c|}
\hline & $\begin{array}{l}(1) \\
\text { OLS }\end{array}$ & $\begin{array}{c}(2) \\
\text { Logit }\end{array}$ & $\begin{array}{c}(3) \\
2 \text { SLS }\end{array}$ & $\begin{array}{l}(4) \\
\mathrm{FE}\end{array}$ & $\begin{array}{c}(5) \\
\text { FE 2SLS }\end{array}$ \\
\hline LWICOMP & $\begin{array}{c}-0.0057 \\
(0.0469)\end{array}$ & $\begin{array}{c}0.0381 \\
(0.4057)\end{array}$ & $\begin{array}{c}0.2207 \\
(0.1172)^{*}\end{array}$ & $\begin{array}{c}0.0207 \\
(0.0752)\end{array}$ & $\begin{array}{c}0.2824 \\
(0.2451)\end{array}$ \\
\hline Computer Investment & $\begin{array}{c}-0.0213 \\
(0.0079)^{* * *}\end{array}$ & $\begin{array}{c}-0.1770 \\
(0.0724)^{* *}\end{array}$ & $\begin{array}{c}-0.0220 \\
(0.0079)^{* * *}\end{array}$ & $\begin{array}{c}-0.0563 \\
(0.0172)^{* * *}\end{array}$ & $\begin{array}{c}-0.0577 \\
(0.0173)^{* * *}\end{array}$ \\
\hline Shipments (\$mil) & $\begin{array}{c}-0.0104 \\
(0.0032)^{* * *}\end{array}$ & $\begin{array}{c}-0.0883 \\
(0.0341)^{* * *}\end{array}$ & $\begin{array}{c}-0.0102 \\
(0.0032)^{* * *}\end{array}$ & $\begin{array}{c}-0.0174 \\
(0.0078)^{* *}\end{array}$ & $\begin{array}{c}-0.0171 \\
(0.0076)^{* *}\end{array}$ \\
\hline Capital/Value-Added & $\begin{array}{c}-0.0002 \\
(0.0001)^{* * *}\end{array}$ & $\begin{array}{c}-0.0010 \\
(0.0003)^{* * *}\end{array}$ & $\begin{array}{c}-0.0002 \\
(0.0001)^{* * *}\end{array}$ & $\begin{array}{c}-0.0001 \\
(0.0001)\end{array}$ & $\begin{array}{l}-0.0001 \\
(0.0001)\end{array}$ \\
\hline Multi-Unit Firm & $\begin{array}{c}0.0456 \\
(0.0028)^{* * *}\end{array}$ & $\begin{array}{c}0.3826 \\
(0.0222)^{* * *}\end{array}$ & $\begin{array}{c}0.0455 \\
(0.0028)^{* * *}\end{array}$ & $\begin{array}{c}0.0531 \\
(0.0385)\end{array}$ & $\begin{array}{c}0.0530 \\
(0.0386)\end{array}$ \\
\hline Exports (\$mil) & $\begin{array}{l}-0.0206 \\
(0.0153)\end{array}$ & $\begin{array}{c}-0.2632 \\
(0.2010)\end{array}$ & $\begin{array}{l}-0.0196 \\
(0.0153)\end{array}$ & $\begin{array}{c}-0.0792 \\
(0.0244)^{* * *}\end{array}$ & $\begin{array}{c}-0.0780 \\
(0.0237)^{* * *}\end{array}$ \\
\hline SEIN Age/Rel. Age & $\begin{array}{c}-0.0014 \\
(0.0002)^{* * *}\end{array}$ & $\begin{array}{c}-0.0119 \\
(0.0016)^{* * *}\end{array}$ & $\begin{array}{c}-0.0014 \\
(0.0002)^{* * *}\end{array}$ & $\begin{array}{c}-3.4635 \\
(1.9609)^{*}\end{array}$ & $\begin{array}{c}-3.5066 \\
(1.9647)^{*}\end{array}$ \\
\hline Worker Age & $\begin{array}{c}0.0011 \\
(0.0001)^{* * *}\end{array}$ & $\begin{array}{c}0.0090 \\
(0.0005)^{* * *}\end{array}$ & $\begin{array}{c}0.0011 \\
(0.0001)^{* * *}\end{array}$ & & \\
\hline Female & $\begin{array}{c}0.0104 \\
(0.0012)^{* * *}\end{array}$ & $\begin{array}{c}0.0835 \\
(0.0100)^{* * *}\end{array}$ & $\begin{array}{c}0.0104 \\
(0.0012)^{* * *}\end{array}$ & & \\
\hline Foreign Born & $\begin{array}{c}-0.0169 \\
(0.0019)^{* * *}\end{array}$ & $\begin{array}{c}-0.1423 \\
(0.0159)^{* * *}\end{array}$ & $\begin{array}{c}-0.0170 \\
(0.0019) * * *\end{array}$ & & \\
\hline White & $\begin{array}{c}-0.0086 \\
(0.0016)^{* * *}\end{array}$ & $\begin{array}{c}-0.0689 \\
(0.0127)^{* * *}\end{array}$ & $\begin{array}{c}-0.0086 \\
(0.0016)^{* * *}\end{array}$ & & \\
\hline Year Fixed Effects & Yes & Yes & Yes & Yes & Yes \\
\hline Industry Fixed Effects & Yes & Yes & Yes & Yes & Yes \\
\hline State Fixed Effects & Yes & Yes & Yes & Yes & Yes \\
\hline Clustered SE @ SEIN & Yes & Yes & Yes & Yes & Yes \\
\hline Observations & 850,000 & 850,000 & 850,000 & 550,000 & 550,000 \\
\hline R-Squared & 0.02 & 0.02 & - & 0.14 & - \\
\hline$F$-statistic $(\mathrm{K}-\mathrm{P})$ & - & - & 106.52 & - & 26.265 \\
\hline Hansen $J$ & - & - & 0.031 & - & 0.295 \\
\hline Hansen $J p$-value & - & - & 0.891 & - & 0.5867 \\
\hline
\end{tabular}

Note: ${ }^{*}$ significant at $10 \%$; ${ }^{* *}$ significant at $5 \%$; $* * *$ significant at $1 \%$. Standard errors for estimates for Shipments and Exports are unavailable due to researchers' error in disclosure process, however coefficients and significance levels are correct, and the missing standard errors can be added in revision phase. 